\title{
Influence of shading during different periods upon ear development, grain yield and its com- ponents in two wheat cultivars
}

\author{
Daniel O. CALDIZ \& Santiago J. SARANDÓN* \\ Instituto de Fisiología Vegetal and * Cátedra de Cerealicultura, Facultad de Agronomía, U.N.L.P., C.C. 3l, \\ 1900 La Plata, Argentina
}

Additional key words : Light intensity, spikelet production, floret number, grain set, grain number $m^{-2}$.

Influence de l'ombrage artificiel appliqué à différentes périodes du développement de 2 variétés de blé sur l'évolution de l'épi et les composantes du rendement en grain.

L'influence d'un ombrage artificiel au cours de différentes phases phénologiques du blé a été étudiée chez 2 variétés sur le développement de l'épi, l'accumulation et la distribution de la matière sèche et sur les composantes du rendement en grain.

Les résultats ont montré l'intérêt de la formation d'un nombre potentiel élevé d'épillets déterminé dans les stades précoces du développement du blé. En effet après la formation de l'épillet terminal seulement un certain nombre d'épillets donne des grains. Le nombre d'épillets est déterminé par le rythme et la durée de leur formation et influencé par la longueur de la période allant de la levée au stade double ride ; ces paramètres diffèrent selon la variété. L'ombrage n'a pas entraîné une baisse de la quantité potentielle d'épillets chez la variété traditionnelle Klein Toledo qui s'est montrée moins sensible à cette condition expérimentale que La Paz INTA.

L'ombrage n'a pas modifié le nombre maximum de fleurs qui s'est montré très stable pour les 2 variétés, au moins pour le milieu de l'épi. La réduction du nombre de grains potentiels après que le nombre de fleurs maximum soit atteint n'est pas différente entre les cultivars; ceci montre la grande influence exercée par les phases précoces du développement du blé sur le rendement en grain.

Le nombre potentiel d'épillets par épi et le nombre de grains par épillet semblent avoir été les composantes du rendement les plus importantes par leur influence sur le nombre de grains par épi et le nombre de grains au $\mathrm{m}^{2}$ qui a été le facteur déterminant du rendement.

Mots clés additionnels : Intensité de la lumière, formation d'épillets, nombre de fleurs, établissement du grain, grains par $\mathrm{m}^{2}$. 


\section{INTRODUCTION}

Grain yield in wheat is determined by the genetic potential of each cultivar (AUSTIN et al., 1980) and by the environmental conditions during both the preanthesis (FISCHER, 1975 ; EVANS et al., 1975 ; EVANS, 1978 ) and post-anthesis phases of ear growth (PENDLETON \& WEIBEL, 1965 ; WELBANK et al., 1968 ; WARDLAW, 1970 ; BROCKLEHURST et al., 1978). Under optimal nutrient and water supply, light will be a major factor in competition (DONALD, 1963) and in determination of productivity (MONTEITH, 1981). This is one of the reasons why many workers have used shading during various periods to study its effects upon ear development and yield.

ASPINALL \& PALEG (1973) showed that in barley, the rate of spikelet production increased with increasing irradiance. FRIEND (1965) found that spikelet number per ear is influenced by irradiance soon after inflorescence initiation and EVANS et al. (1975) demonstrated that shading at the early growth stages reduced tiller number.

WILLEY \& HOLLIDAY (1971) and FISCHER (1975) found that shading before anthesis reduced yield to a greater extent than thereafter, particularly if shading occurred during the period of rapid ear growth (35 to 5 days before anthesis). Evans' (1978) results were similar and demonstrated that pre-anthesis irradiance has more influence on yield than post-anthesis irradiance. One reason for this effect is that irradiance tends to be lower ciuring the early stage of developrnent of spring wheat crops in the field, which might account for the greater impact of shading at that time. Nevertheless, WARDLAW (1970) found that grain set is the most critical period for shading and SPIERTZ (1979) conciuded that reducing irradiance during the cell expansion phase decreased the rate of dry matter accumulation in the grain, and thus grain weight at maturity.

These conflicting statements led GALLAGHER (1979) and SPIERTZ \& VAN KEULEN (1980) to suggest that there are still many areas requiring further research : for example, the relationships between floral development and dry matter accumulation and the alternative pathways that allow floret survival and lead to greater grain number $\mathrm{m}^{-2}$.

Our main objective was to study the influence of shading during various periods on ear and floret development in relation to dry matter accumulation and its distribution in two wheat cultivars.

\section{MATERIALS AND METHODS}

A tall standard cultivar, Klein Toledo, and a semidwarf one, La Plaz INTA were sown 26th July 1984 in the Experimental Station "Julio Hirschhorn" (Los Hornos, SL $34^{\circ} 54^{\prime}$ ) in a typical Argiudol soil. Plant density was $300 \mathrm{~m}^{-2}$, sown in plots of 6 rows, $0.20 \mathrm{~m}$ apart and $4.5 \mathrm{~m}$ long, distributed in a randomized block design with 4 replications. N-P-K (18-46-0; $65 \mathrm{~kg} \mathrm{ha}^{-1}$ ) was applied at sowing. Weeds, diseases and pests were controlled as normally done.

The following shading treatments were applied to five different plots after emergence $(18 / 8 / 84)$ :
$\mathrm{C}$ : Control, i.e. no shading during crop cycle.

$\mathrm{S}_{1}$ : Shading from emergence till maximum spikelet number (MSN) or terminal spikelet stage (TS).

$\mathrm{S}_{2}$ : Shading from MSN till maximum floret number (MFN).

$\mathrm{S}_{3}$ : Shading from MFN till anthesis.

$\mathrm{S}_{4}$ : Shading from anthesis till grain maturity.

Shading treatments were carried out over $1 \mathrm{~m}^{2}$ per plot with a double layer of plastic gray mosquito mesh that decreased light intensity by $50 \%$ without modifying light quality (fig. 1). The shading structure was lifted up progressively according to plant height. Air movement was normal.

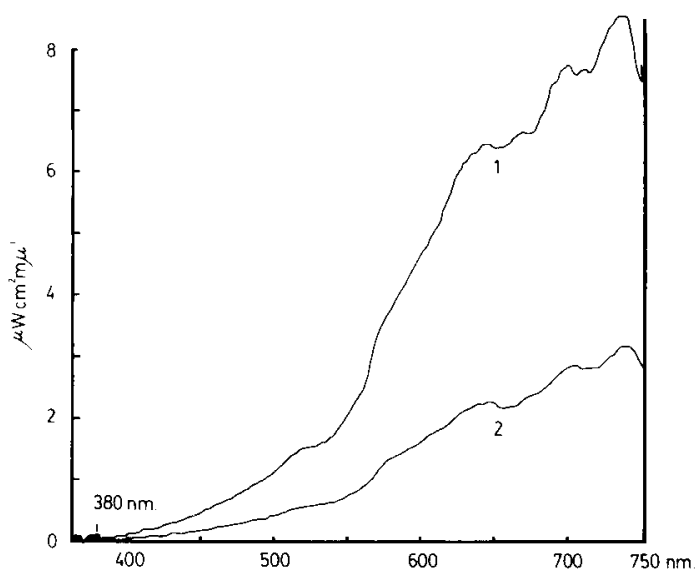

Figure 1

Light reduction by shading.

Réduction de la lumière par l'ombrage.

Tungsten bulb (1) ; Tungsten bulb + double plastic gray mosquito mesh (2).

The following parameters were measured on 10 plants per replication at the end of each shading period: at the 1st harvest, tiller number (TN) per plant, total dry weight per plant (TDW), spikelet number, apex length and number of green leaves; at the 2nd harvest, the parameters measured in the 1 st harvest plus maximum floret number per spikelet in the middle portion of the ear ( 5 ears and 4 spikelets per ear, each replication) ; at the 3rd harvest, the parameters measured in the 1st harvest plus floret number per spikelet and dry matter distribution (DMD) within leaves, stems and ears. Spikelet number, ear length and floret number were measured on the main stems of 10 plants that were chosen at random within each plot.

At the 4 th and final harvest, the following parameters were measured for $0.20 \mathrm{~m}^{2}$ of each treated plots : ears $\mathrm{m}^{-2}$, ear weight, total and fertile spikelet number per ear, grain number per ear in the central portion of the ear (10 ears, 4 spikelets per ear), total grain number per ear $(\mathrm{GN})$, grain weight $(\mathrm{GW})$, harvest index $(\mathrm{HI})$, grain yield and dry matter distribution.

To determine the beginning and end of each developmental stage and treatment, apeces were regularly dissected and observed with a stereoscopic microscope BAUSCH \& LOMB ASZ 45E, according to the methods of MONCUR (1981) and BONNET (1983). The double ridge stage was considered according to stage 3 and $D$ of MONCUR (1981) and BONNET (1983), respectively. 
To calculate the reduction in potential grain sites per ear, average maximum spikelet number per ear and average maximum floret number per spikelet and per cultivar were considered at those stages. Average values per cultivar were used for any other calculations.

The data were treated by a factorial analysis and LSD values were determined by Tukey's test $(\mathrm{P}<0.05)$. When the data in the tables do not specify cultivar differences, no interactions between cultivar and treatment existed.

Meteorological data during crop growing are presented in figure 2.

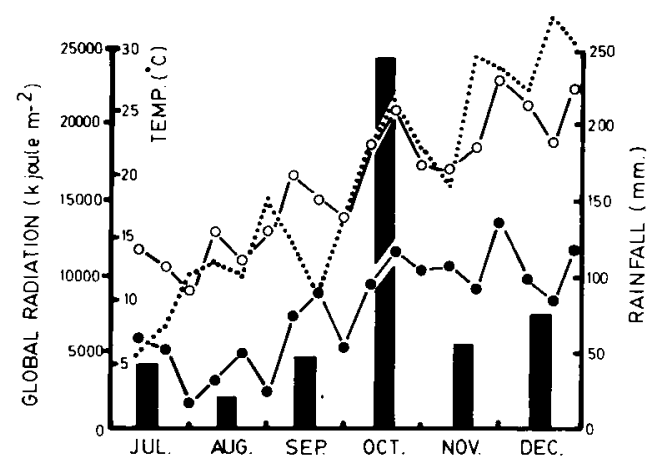

Figure 2

Meteorological data during crop growing.

Maximum medium (-○) and minimum medium (-๑) tempera-

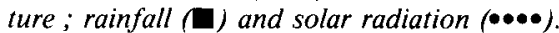

Données météorologiques pendant la culture.

Températures moyenne maximale $(-\bigcirc)$ et moyenne minimale

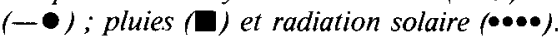

\section{RESULTS AND DISCUSSION}

There are many interesting relationships between yield components that interact to determine final grain yield in wheat.

Leaf number and tiller number per plant are important at the early growth stages (GALLAGHER, 1979). Leaf and tiller numbers were significantly reduced by $S_{1}$ (table 1), as reported earlier by EvANs et al. (1975). At this early growth stage, apex length was also reduced and positively correlated with spikelets per ear and total dry weight per plant $\left(\mathrm{r}: 0.880^{\# \#}\right.$ and $0.791^{\# \#}$ respectively). $S_{1}$ also reduced in La Paz INTA spikelets

\section{TABLE I}

Leaf number, tiller number, spikelet per ear, ear length and total dry weight per plant at the end of $S_{l}$.

Nombre de feuilles, nombre de tiges, d'épillets par épi, longueur de l'épi et poids total par plante à la fin de $S_{l}$.

\begin{tabular}{lcccccc}
\hline \hline & $\begin{array}{c}\text { Leaf } \\
\text { number }\end{array}$ & $\begin{array}{c}\text { Tiller } \\
\text { number }\end{array}$ & $\begin{array}{c}\text { Spikelets } \\
\text { KT }\end{array}$ & $\begin{array}{c}\text { Per ear } \\
\text { LP }\end{array}$ & $\begin{array}{c}\text { Ear } \\
\text { length* }\end{array}$ & $\begin{array}{c}\text { TDW } \\
(\mathrm{g})\end{array}$ \\
\hline Control & $6.56^{\mathrm{a}}$ & $2.94^{\mathrm{a}}$ & $15.70^{\mathrm{a}}$ & $23.05^{\mathrm{a}}$ & $2.60^{\mathrm{a}}$ & $0.62^{\mathrm{a}}$ \\
$\mathrm{S}_{1}$ & $6.01^{\mathrm{b}}$ & $2.44^{\mathrm{b}}$ & $15.39^{\mathrm{a}}$ & $20.70^{\mathrm{b}}$ & $2.20^{\mathrm{b}}$ & $0.49^{\mathrm{b}}$ \\
$\%_{0} \mathrm{vc}$ & 4.85 & 10.97 & 2.74 & 2.74 & 11.88 & 12.95 \\
\hline
\end{tabular}

* in mm. Within columns figures followed by the same letter do not differ.

Dans chaque colonne, les valeurs suivies par la même lettre ne diffèrent pas statistiquement entre elles.

KT : Klein Toledo ; LP : La Paz INTA

$\%$ ve : variability coefficient.

per ear, but not in Klein Toledo, possibly because tall standard cultivars are better buffered against assimilate shortage as suggested by FISCHER \& HILLE RIS LAMBERS (1978). ASPINALl \& PALEG (1963), FRIEND (1965) and WILLEY \& HOLLIDAY (1971) had shown that bright light increased spikelet production, probably due to greater availability of assimilates.

The greater spikelet number per ear in LP (table 1) was probably due to the substantial length of the period from emergence to double ridge stage (fig. 3), as previously mentioned by RAWSON (1970). Moreover, the spikelet production rate were lower in Klein Toledo ( 11 days, 1.41 spikelets day ${ }^{-1}$ ) than in $\mathrm{La} \mathrm{Paz}$ INTA ( 13 days, 1.68 spikelets day ${ }^{-1}$ ). This allowed the latter, a semi-dwarf cultivar, to achieve a greater spikelet number, which, in turn, was associated with a higher total dry weight per plant, particularly at the end of $\mathrm{S}_{2}$ (fig. 4 and 5).

Shading did not modify maximum floret number either in Klein Toledo or in La Paz INTA, probably because the central portion of the ear is the least sensitive to environmental insults. Nevertheless, maximum floret number and ear length (table 2 ) showed a negative relationship $\left(r:-0.409^{\#}\right)$.

Spikelet number per ear did not decrease in Klein Toledo during $\mathrm{S}_{2}$ but decreased $15 \%$ in La Paz INTA (fig. 5). This suggests that each cultivar achieves final yield through different mechanisms.

A natural decrease of 16 and $18 \%$ in spikelet number per ear was observed during $\mathrm{S}_{3}$ for La Paz INTA and Klein Toledo, respectively. In relation to potential

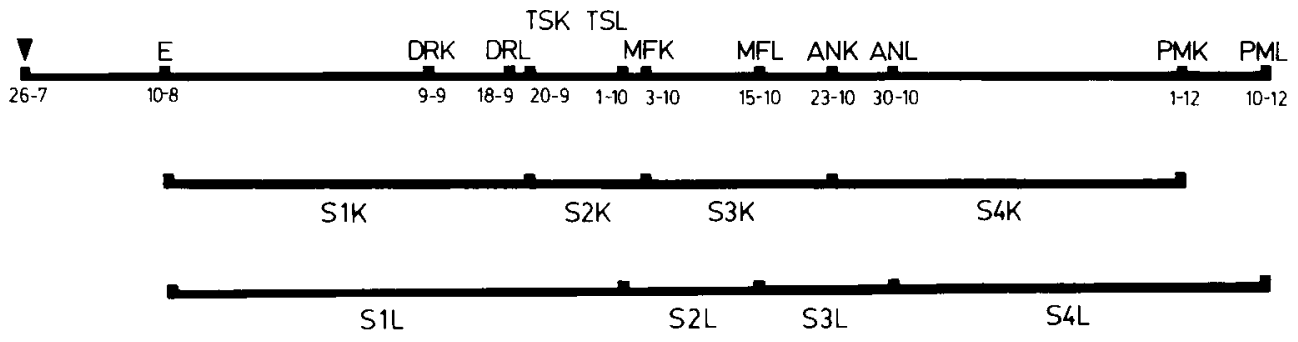

Figure 3

Crop phenological phases.

$K:$ Klein Toledo ; $L$ : La Paz INTA ; $\mathbf{\nabla}$ : sowing ; $E$ : emergence $S_{l}$ to $S_{4}$ : shading periods; $D R$ : double ridge stage ; TS : terminal spikelet; $M F$ : Maximum floret number; $A N$ : anthesis; $P M$ : physiological maturity.
Phases phénologiques de la culture.

$K$ : Klein Toledo ; $L$ : La Paz INTA ; $\boldsymbol{\nabla}$ : semis ; E : levée ; $S_{-} S_{4}$ : périodes d'ombrage; $D R$ : double ride ; TS : épillet terminal ; $M F$ : nombre maximum de fleurs; $A N$ : floraison; $P M$ : maturité physiologique. 


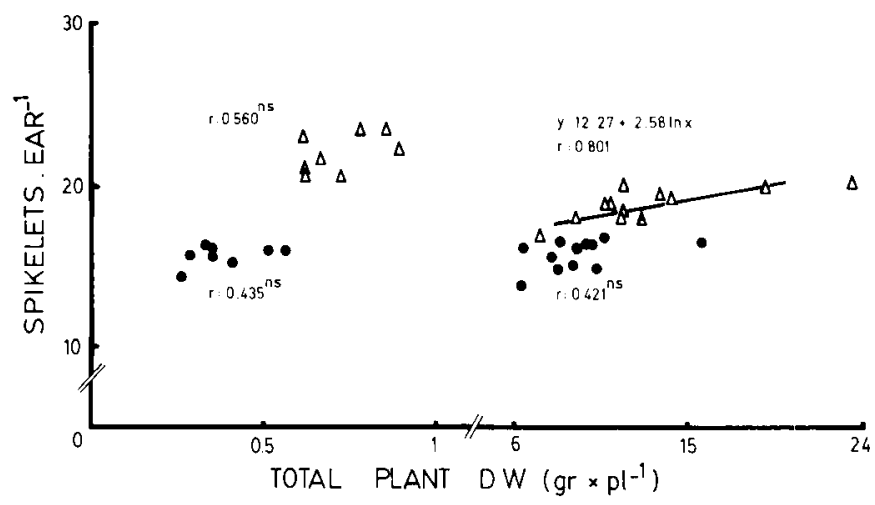

Figure 4

Relationships between spikelets per ear and TDW per plant at the end of $S_{1}$ and $S_{2}$.

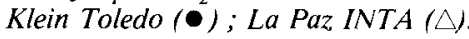

Relation entre le nombre d'épillets par épi et le poids sec total (TDW) par plante à la fin de $S_{1}$ et $S_{2}$.

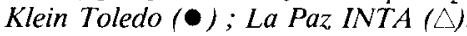

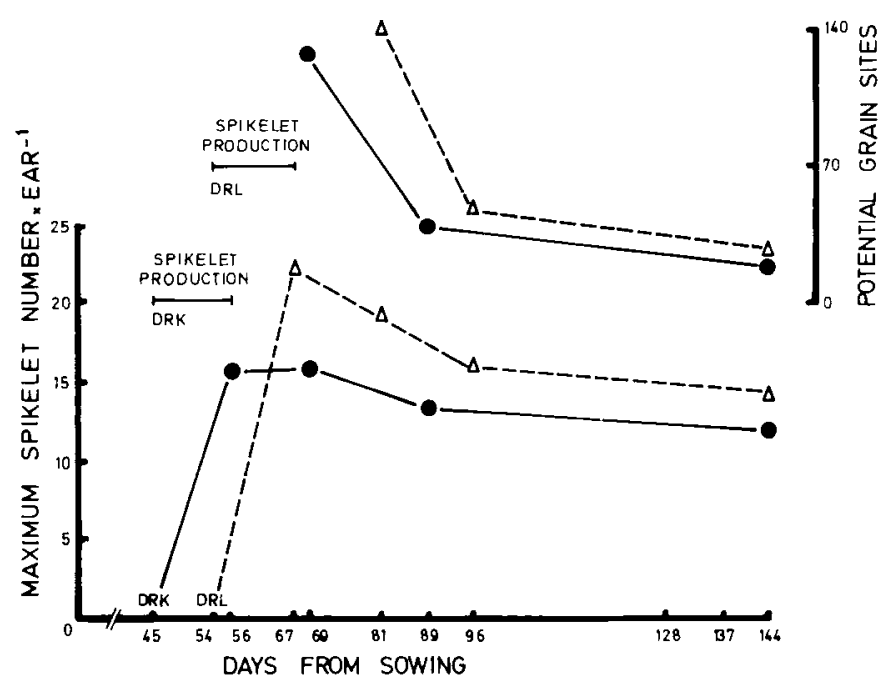

Figure 5

Spikelet production and reduction in the number of potential grain sites.

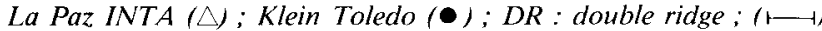
spikelet production period (in days).

Production d'épillets et réduction du nombre de grains potentiels.

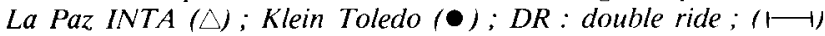
période de production des épillets (en jours).

TABLE 2

Leaf number, tiller number, spikelets per ear, ear length, maximum floret number and total dry weight per plant at the end of $S_{2}$

Nombre de feuilles, nombre de tiges, épillets par épi, longueur de l'épi, nombre maximum de fleurs et poids sec total par plante à la fin de $S_{2}$.

\begin{tabular}{|c|c|c|c|c|c|c|c|}
\hline & $\begin{array}{c}\text { Leaf } \\
\text { number }\end{array}$ & $\begin{array}{c}\text { Tiller } \\
\text { number }\end{array}$ & $\begin{array}{l}\text { Spikelets } \\
\text { KT }\end{array}$ & $\begin{array}{l}\text { Per ear } \\
\text { LP }\end{array}$ & $\begin{array}{c}\text { Ear } \\
\text { length* }\end{array}$ & MFN & $\begin{array}{c}\text { TDW } \\
\text { (g) }\end{array}$ \\
\hline Control & $6.95^{\mathrm{ab}}$ & $2,48^{\mathrm{a}}$ & $15.45^{\mathrm{a}}$ & $18.90^{\mathrm{ab}}$ & $27.02^{\mathrm{a}}$ & $7.59^{\mathrm{a}}$ & $12.92^{\mathrm{a}}$ \\
\hline $\mathrm{S}_{1}$ & $6.2^{\mathrm{b}}$ & $2,17^{\mathrm{a}}$ & $15.75^{\mathrm{a}}$ & $19.35^{\mathrm{a}}$ & $21.56^{\mathrm{a}}$ & $7.54^{\mathrm{a}}$ & $10.57^{a}$ \\
\hline $\mathrm{S}_{2}$ & 7. & $2,47^{\mathrm{a}}$ & $16.03^{\mathrm{a}}$ & $18.05^{b}$ & $24.81^{\mathrm{a}}$ & $7.71^{\mathrm{a}}$ & $9.91^{\mathrm{a}}$ \\
\hline$\%$ vc & 3. 1 & 20.96 & 3.24 & 3.24 & 23.53 & 6.32 & 28.13 \\
\hline
\end{tabular}

* in $\mathrm{mm}$.

Within columns , gures followed by the same letter do not differed. Dans chaque colonne, les valeurs suivies par la même lettre ne diffèrent pas statistiquement entre elles.

KT : Klein Toledo : LP : La Paz INTA. grain sites, this reduction was $69 \%$ for La Paz INTA and $70 \%$ for Klein Toledo. The total dry weight per plant was also reduced during $S_{3}$ (table 3 ), a result in agreement with PENDLETON \& WEIBEL (1965).

\section{TABLE 3}

Leaf number, tiller number, spikelet per ear, ear length, floret number per spikelet and total dry weight per plant at the end of $S_{3}$ for both cultivars*

Nombre de feuilles, nombre de tiges, épillets par épi, longueur de l'épi, nombre de fleurs par épillet et poids sec total par plante à la fin de $S_{3}$ par les 2 variétés*.

\begin{tabular}{lcccccc}
\hline & $\begin{array}{c}\text { Leaf } \\
\text { number }\end{array}$ & $\begin{array}{c}\text { Tiller } \\
\text { number }\end{array}$ & $\begin{array}{c}\text { Spikelet } \\
\text { per ear }\end{array}$ & $\begin{array}{c}\text { Floret } \\
\text { number } \\
\text { per } \\
\text { spikelet }\end{array}$ & $\begin{array}{c}\text { Ear } \\
\text { length** }\end{array}$ & $\begin{array}{c}\text { TDW } \\
(\mathrm{g})\end{array}$ \\
\hline Control & $2,82^{\mathrm{a}}$ & $1.72^{\mathrm{a}}$ & $14.97^{\mathrm{a}}$ & $2.92^{\mathrm{a}}$ & $76.55^{\mathrm{a}}$ & $22.95^{\mathrm{a}}$ \\
$\mathrm{S}_{1}$ & $2,86^{\mathrm{a}}$ & $1.48^{\mathrm{ab}}$ & $14.87^{\mathrm{a}}$ & $2.80^{\mathrm{a}}$ & $77.37^{\mathrm{a}}$ & $20.30^{\mathrm{ab}}$ \\
$\mathrm{S}_{2}$ & $2,98^{\mathrm{a}}$ & $1.38^{\mathrm{b}}$ & $13.90^{\mathrm{ab}}$ & $2.57^{\mathrm{a}}$ & $73.70^{\mathrm{ab}}$ & $18.43^{\mathrm{ab}}$ \\
$\mathrm{S}_{3}$ & $2,86^{\mathrm{a}}$ & $1.48^{\mathrm{ab}}$ & $13.63^{\mathrm{b}}$ & $2.72^{\mathrm{a}}$ & $71.54^{\mathrm{b}}$ & $18.13^{\mathrm{ab}}$ \\
$\mathbf{\%}_{0 \mathrm{vc}}$ & 7.80 & 12.10 & 5.44 & 7.70 & 4.72 & 13.20 \\
\hline \hline
\end{tabular}

* : Mean values of both cultivars. Valeur moyenne des 2 variétés. **: in $\mathrm{mm}$.

Within columns figures followed by the same letter do not differed Dans chaque colonne, les valeurs suivies par la même lettre ne diffèrent pas statistiquement entre elles.

The $\mathrm{S}_{3}$ treatment reduced spikelet number per ear and ear length, but reduction in floret number per spikelet was not significant at the end of $S_{3}$ (table 3). Although, this treatment evidently affected later grain set, as it is evident from data obtained for grain number per spikelet at the final harvest (table 4) ; similar results were found by WARDLAW (1970).

BROCKLEHURST et al. (1978) found that reduced irradiance during the cell production phase decreased grain weight by $13 \%$ when sampled 14 days after anthesis, while in our results grain weight was only reduced $5.3 \%$, a non-significant change (table 4). Additionally, a natural reduction of 9 and $11 \%$ in fertile spikelets per ear and of 54 and $41 \%$ in total grain sites were observed ciuring $\mathrm{S}_{4}$ for Klein Toledo and La $\mathrm{Paz}$ INTA, respectively. This reduction led to an analogous reduction in potential grain sites from the end of $\mathrm{S}_{2}$ onwards ( 86 and $82 \%$ for Klein Toledo and La $\mathrm{Paz}$ INTA, respectively). Hence derives the importance of the initial growth stages, where the maximum floret number is achieved.

We found no evidence for preferential allocation of assimilates to grain (table 4), which contrasts with the results of BREMNER (1972) and FISCHER (1975). Our results possibly may be explained by low temperature during grain filling (fig. 1), which extended the filling period ; thus, full light was not as necessary to achieve normal grain weight, a suggestion made SPIERTZ (1974).

Shading reduced tiller number and spikelet number per plant during the early growth stages, which modified the number of ears $\mathrm{m}^{-2}$ and fertile spikelet number per plant at harvest. After anthesis, shading reduced grain set and, therefore grain ear ${ }^{-1}$ at harvest. Altogether these components modified grain number $\mathrm{m}^{-2}$, in accordance with EVANS (1978), which resulted

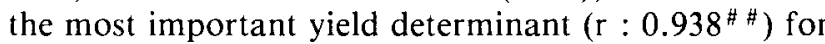
both cultivars (fig. 6). 
TABLE 4

Yield components and total grain yield at the final harvest for both cultivars*.

Composantes $d u$ rendement et rendement total en grain dans la récolte finale pour les 2 variétés*.

\begin{tabular}{|c|c|c|c|c|c|c|c|c|c|c|c|c|}
\hline & $\begin{array}{c}\text { Ears } \\
\text { per } \\
\mathrm{m}^{2}\end{array}$ & $\begin{array}{c}\text { Ear } \\
\text { wght. } \\
\text { (g) }\end{array}$ & $\begin{array}{l}\text { Fert. } \\
\text { spik. } \\
\text { ear }\end{array}$ & $\begin{array}{l}\text { Grain** } \\
\text { number. } \\
\text { spikel }^{-1}\end{array}$ & $\begin{array}{l}\text { Grain } \\
\text { number. } \\
\text { spikel }^{-1}\end{array}$ & $\begin{array}{c}\text { Grain } \\
\text { number. } \\
\text { ear }^{-1}\end{array}$ & $\begin{array}{c}\text { Grain } \\
\text { weight } \\
(\times \quad 1000)\end{array}$ & $\begin{array}{c}\text { Grain } \\
\mathrm{m}^{-2}\end{array}$ & $\begin{array}{c}\text { Grain } \\
\text { yield } \\
\mathrm{kg} . \mathrm{ha}^{-1}\end{array}$ & $\begin{array}{l}\text { Dry Matter } \\
\text { Leaves }\end{array}$ & $\begin{array}{l}\text { Distrib } \\
\text { Stems }\end{array}$ & $\begin{array}{c}\text { ion }(0 \%) \\
\text { Ears }\end{array}$ \\
\hline $\begin{array}{l}\text { Control } \\
S_{1} \\
S_{2} \\
S_{3} \\
S_{4} \\
0_{0} \text { vc }\end{array}$ & $\begin{array}{l}485^{\mathrm{a}} \\
373^{\mathrm{b}} \\
418^{\mathrm{a}} \\
398^{\mathrm{b}} \\
416^{\mathrm{a}} \\
13.70\end{array}$ & $\begin{array}{c}1.26^{\mathrm{a}} \\
0.98^{\mathrm{b}} \\
1.10^{\mathrm{ab}} \\
0.98^{\mathrm{b}} \\
1.10^{\mathrm{ab}} \\
14.25\end{array}$ & $\begin{array}{c}13.82^{\mathrm{a}} \\
12.48^{\mathrm{bc}} \\
12.74^{\mathrm{bc}} \\
12.23^{\mathrm{c}} \\
13.24^{\mathrm{ab}} \\
5.40\end{array}$ & $\begin{array}{l}2.20^{\mathrm{a}} \\
1.80^{\mathrm{b}} \\
2.07^{\mathrm{a}} \\
1.90^{\mathrm{b}} \\
2.21^{\mathrm{a}} \\
8.68\end{array}$ & $\begin{array}{c}1.70^{\mathrm{a}} \\
1.50^{\mathrm{b}} \\
1.58^{\mathrm{ab}} \\
1.54^{\mathrm{b}} \\
1.78^{\mathrm{a}} \\
10.11\end{array}$ & $\begin{array}{l}23.79^{\mathrm{a}} \\
19.06^{\mathrm{b}} \\
20.45^{\mathrm{ab}} \\
19.03^{\mathrm{b}} \\
23.97^{\mathrm{a}} \\
13.00\end{array}$ & $\begin{array}{c}39.72^{\mathrm{a}} \\
36.95^{\mathrm{a}} \\
39.85^{\mathrm{a}} \\
38.04^{\mathrm{a}} \\
37.61^{\mathrm{a}} \\
8.73\end{array}$ & $\begin{array}{r}11278^{\mathrm{a}} \\
7039^{\mathrm{bc}} \\
7914^{\mathrm{b}} \\
7445^{\mathrm{bc}} \\
9770^{\mathrm{ab}} \\
18.35\end{array}$ & $\begin{array}{c}4498^{\mathrm{a}} \\
2655^{\mathrm{bc}} \\
3195^{\mathrm{b}} \\
2885^{\mathrm{bc}} \\
3590^{\mathrm{a}} \\
21.26\end{array}$ & $\begin{array}{c}15.91^{\mathrm{a}} \\
15.08^{\mathrm{a}} \\
15.07^{\mathrm{a}} \\
15.18^{\mathrm{a}} \\
16.06^{\mathrm{a}} \\
8.63\end{array}$ & $\begin{array}{c}35.21^{\mathrm{a}} \\
35.38^{\mathrm{a}} \\
35.16^{\mathrm{a}} \\
36.63^{\mathrm{a}} \\
33.19^{\mathrm{a}} \\
7.87\end{array}$ & $\begin{array}{c}48.70^{\mathrm{a}} \\
49.53^{\mathrm{a}} \\
50.60^{\mathrm{a}} \\
48.17^{\mathrm{a}} \\
50.73^{\mathrm{a}} \\
6.40\end{array}$ \\
\hline
\end{tabular}

* Mean values for both cultivars. Valeur moyenne des 2 variétés.

** In the central portion of the ear.

Within columns figures followed by the same letter do not differ.

Dans chaque colonne, les valeurs suivies par la même lettre ne diffèrent pas statistiquement entre elles.

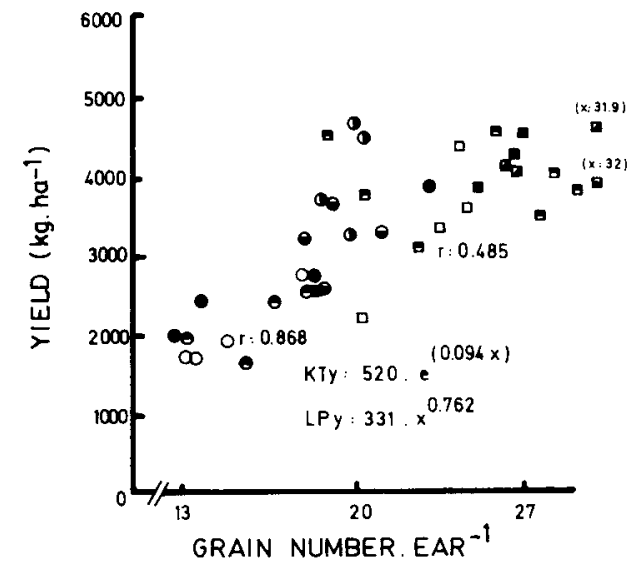

-
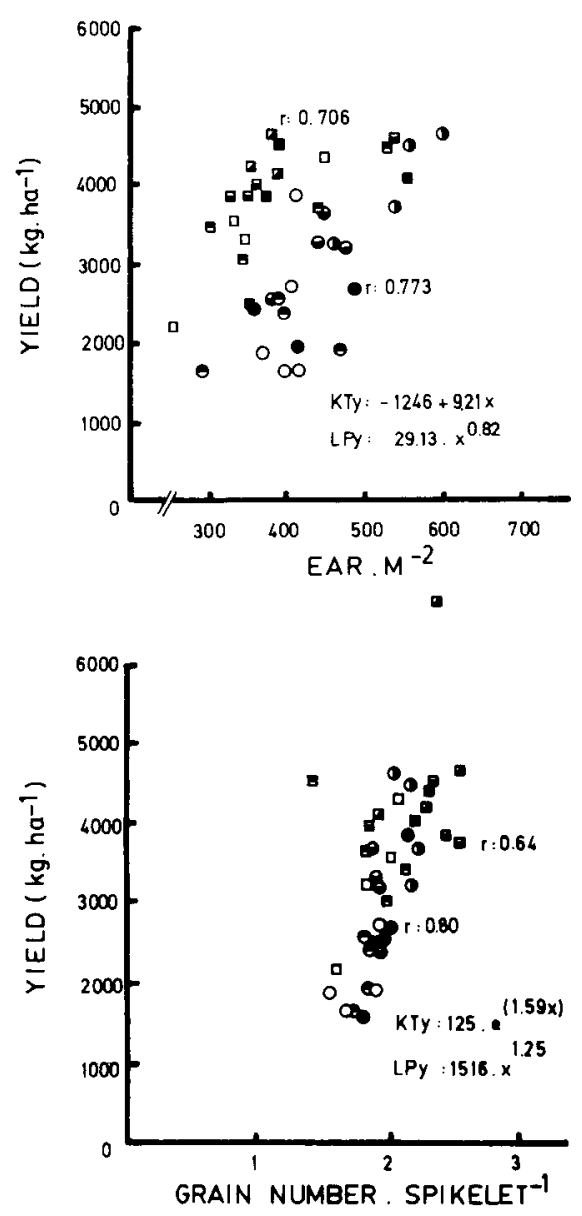
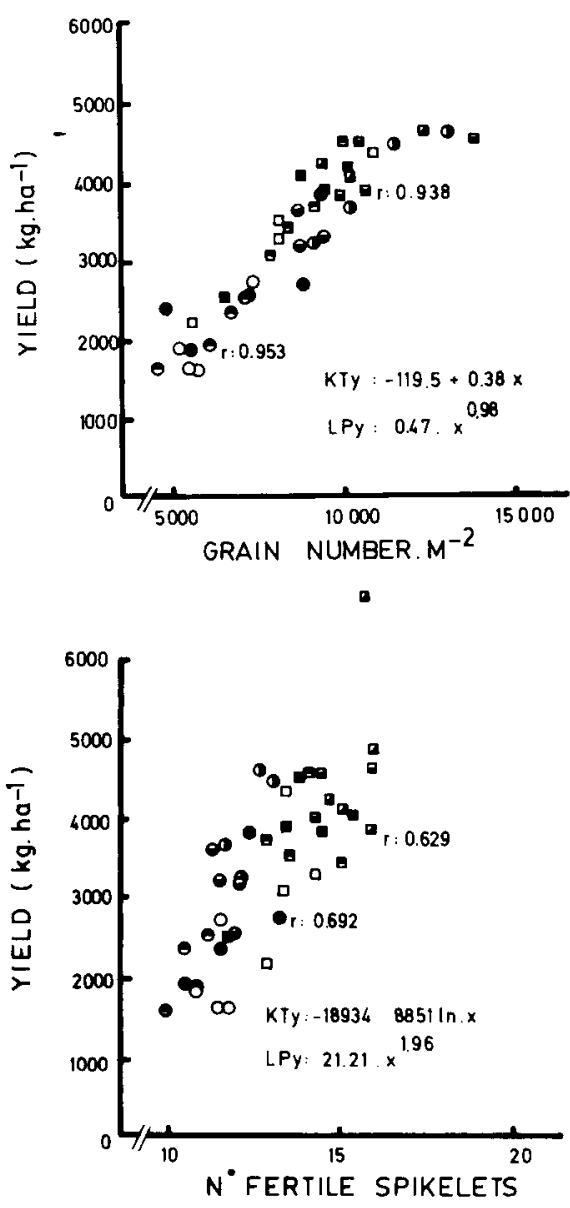

Figure 6

Relationship between grain yield and some yield components.

(@) Control; (O) $S_{1} ;(\bullet) S_{2} ;(\Theta) S_{3}$ and $(\Theta) S_{4}$ for Klein Toledo

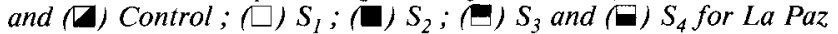
INTA.

Each point is the mean value for 15 data.

Relation entre le rendement en grain et quelques composantes du rendement.

() Témoin; $(0) S_{1} ;(\bullet) S_{2} ;(\Theta) S_{3}$ et (Ө) $S_{4}$ par Klein Toledo et (C) Témoin; (ঢ) $S_{1} ;$ (日) $S_{2}$; (E) $S_{3}$ et (U) $S_{4}$ par La Paz INTA. Chaque point représente la moyenne de 15 données. 


\section{CONCLUSIONS}

Our results show that achieving a high number of potential spikelets during the early growth stages is very important, because of the natural reduction in fertile spikelet number that follows.

Shading decreased leaf and tiller number at the early growth stages and spikelet number was reduced only in the semi-dwarf cultivar (La Paz INTA), probably because tall cultivars are better buffered against unfavorable environment.

Maximum floret number was not modified by shading and appears to be very stable in both cultivars, at least in the central portion of the ear. Reduction in potential grain sites after maximum floret number has been reached did not differ between cultivars and, therefore, shows the great influence that the previous phases exert on achieving grain yield.
Grain set was affected by shading periods before anthesis in both cultivars. Potential spikelet number per ear and grain number per spikelet appeared to be the most important yield components, due to their influence upon grain number per ear and hence grain yield $\mathrm{m}^{-2}$, which was the main yield determinant.

Reçu le 8 juillet 1986. Accepté le 19 janvier 1988.

\section{ACKNOWLEDGEMENTS}

Thanks are due to Miss L. del C. MarChán and Mr C. Della CROCE for valuable technical assistance, to E. R. MONTALDI for critical reading of the manuscript and to Dr W. LIPTON FrEsNo (California) for language editing.

This work is part of the Research Program PRINFIVE (CONICET - UNLP) and DOC and SJS are Researcher and Post-graduate fellow from CONICET, respectively.

\section{REFERENCES}

Aspinall D., Paleg L. G., 1963. Effects of day length and light intensity on growth of barley. I. Growth and development of the anex with a fluorescent light source. Bot. Gaz., 124, 429-437.

Austin R. B., Bingham J., Blackwell R. D., Evans L. T., Ford M. A., Morgan C. L., Taylor M., 1980. Genetic improvements in winter wheat since 1900 and associated physiological changes. J. Agric Sci. Cambridge, 94, 675-689.

Bonnet O. T., 1983. Las inflorescencias de maíz, trigo, centeno, cebada y avena. Su iniciación y desarrollo. Hemisferio Sur S. A., Buenos Aires, 29-47.

Bremner P. M., 1972. Accumulation of dry matter and nitrogen by grains in different positions of the wheat ear as influenced by shading and defoliation. Aust. J. Biol. Sci., 25, 657-668.

Brocklehurst P. A., Moss J. P., Williams W., 1978. Effects of irradiance and water supply on grain development in wheat. Ann. Appl. Biol., 90, 265-276.

Donald C. M., 1963. Competition among crop and pasture plants. Adv. Agron., 15, 1-118.

Evans L. T., 1978. The influence of irradiance before and after anthesis on grain yield and its components in microcrops of wheat grown in a constant day length and temperature regime. Field Crops Res., 1, 5-19.

Evans L. T., Wardlaw I. F., Fischer R. A., 1975. Wheat. In : L. T. Evans (Editor), Crop Physiology. Some case histories. Cambridge University Press, 101-149.

Fischer R. A., 1975. Yield potential in a dwarf spring wheat and the effect of shading. Crop Sci., 15, 607-613.

Fischer R. A., Hille Ris Lambers D., 1978. Effect of environment and cultivar on source limitation to grain weight in wheat. Aust. $J$. Agric. Sci., 29, 443-458.

Friend D. J. C., 1965. Ear length and spikelet number of wheat grown at different temperatures and light intensities. Can. J. Bot., $43,345-353$.
Gallagher J. N., 1979. Ear development : processes and prospects. Crop Physiology and Cereal Breeding. Proc. Eucarpia Workshop (Wageningen), 3-9.

Moncur M. W., 1981. Floral initiation in field crops. CSIRO. Melbourne National Library of Australia, $135 \mathrm{p}$.

Monteith J. L., 1981. Does light limit crop production? In : C. B. Johnson (Editor) Physiological Processes Limiting Plant Productivity. Butterworths, London, 23-38.

Pendleton J. W., Weibel R. O., 1965. Shading studies on winter wheat: Agron. J., 57, 292-293.

Rawson H. M., 1970. Spikelet number, its control and relation to yield per ear in wheat. Aust. J. Biol. Sci., 23, 1-15.

Spiertz J. H. J., 1974. Grain growth and distribution of dry matter in the wheat plant as influenced by temperature, light energy and ear size. Neth. J. Agric. Sci., 22, 207-220.

Spiertz J. H. J., 1979. Weather and nitrogen effects on rate and duration of grain growth and on grain yield of wheat cultivars. Crop Physiology and Cereal Breeding. Proc. Eucarpia Workshop (Wageningen), 14-16.

Spiertz J. H. J., Van Keulen H., 1980. Effects of nitrogen and water supply on growth and grain yield of wheat. Proc. 3rd International Wheat Conf. (Madrid), 595-610.

Wardlaw I. F., 1970. The early stages of grain development in wheat : response to light and temperature in a single variety. Aust. J. Biol. Sci., 23, 765-774.

Welbank P. J., Witts K. J., Thorne G. N., 1968. Effect of radiation and temperature on efficiency of cereal leaves during grain growth. Ann. Bot., 32, 79-95.

Willey R. W., Holliday R., 1971. Plant population, shading and thinning studies in wheat. J. Agric. Sci. Cambridge, 77, 453-461. 